\title{
ИННОВАЦИОННЫЕ ЛЕКАРСТВЕННЫЕ ФОРМЫ
}

\author{
Э.Ф. Степанова \\ Кафедра фармацевтической технологии с курсом медицинской биотехнологии, \\ Пятигорский медико-фармацевтический институт - \\ филиал ФГБОУ ВО ВолгГМУ МЗ РФ, 357500, Россия, г. Пятигорск, ул. Кирова, 33.
}

DOI: 10.19163/MedChemRussia2021-2021-192_E-mail: efstepanova@yandex.ru

Лекарственная форма (ЛФ), одно из базовых понятий фармации, продолжает с годами наращивать свою значимость. Именно поэтому для лекарственных форм появилось много характеристических терминов, не входящих в традиционные классификационные рамки, которые и обсуждаются в настоящем докладе. Одним из таких понятий является безусловно емкое определение - инновационные. Инновационные лекарственные формы - это оригинальные, запатентованные ЛФ, обладающие медицинскими, фармацевтическими и потребительскими преимуществами перед существующими традиционными ЛФ.

В настоящее время групп, которые можнобыло бы причислить к инновационным довольно много, поэтому можно выделить два центральных направления среди многочисленных инновационных ЛФ: это быстрорастворимые ЛФ и пролонгированные. Быстрорастворимыми при определенных условиях могут быть многие твердые лекарственные формы - гранулы, капсулы, микрокапсулы, пеллеты. Но наиболее вариабельны в этом отношении таблетки - это диспергируемые, ородисперсные, растворимые и рапид. А также доминирующие по всем показателям - шипучие таблетки.

Быстрорастворимые лекарственные формы обеспечивают высокую биологическую доступность действующих веществ, и в то же время существуют варианты, обеспечивающие дальнейшее повышение их биологической доступности. В настоящее время с этой целью успешно используются такие инновационные технологии, как криоизмельчение, микронизация, получение полуфабрикатов в виде твердых дисперсий. Но можно достичь увеличения биологической доступности и с помощью некоторых групп вспомогательных веществ, что упрощает общую технологическую схему: это солюбилизаторы, комплексоны (трилон Б, например), суперинтегранты. Все эти быстрорастворимые лекарственные формы находятся в постоянной динамике: совершенствуются не только технологически, но и список их неуклонно растет.

Что касается пролонгированных лекарственных форм и терапевтических систем, то их разработка развивается еще более интенсивно: следует особо отметить трансдермальные и пероральные терапевтические системы.

В отношении таблетированных лекарственных форм (как наиболее востребованных) можно отметить их разнообразие. Их широкий список включает в себя таблетки, покрытые пленочной оболочкой, действующие на основе принципа гидродинамического баланса, осмотического насоса; слоистые таблетки, каркасные, матричные таблетки и многие другие. Разнообразны и капсулированные пролонгированные формы, к которым относятся спансулы, капсулы для имплантаций, пролонгированные капсулы и проч. Подобное многообразие позволяет не только повысить комфортность лечения и расширить возможности выбора для больного, но и достичь большей эффективности и безопасности использования лекарственных средств.

$$
-192-
$$

